\title{
New challenges
}

\section{Domingo M. Braile*}

I $t$ is with great satisfaction that I write this, the first editorial after reelection as the Editor-in-Chief of the Brazilian Journal of Cardiovascular Surgery (BJCVS). I would like to thank everyone for the trust they have placed in me and reiterate my commitment to maintain and improve the quality of our journal over the next six years of my term of office. There are new challenges to overcome, but I am sure that this will be possible with work, dedication and the support of all my colleagues.

After achieving the long-dreamed-of indexation in Medline, the objective of the Editorial Board is to be accepted in ISI, too. For this we are preparing a detailed dossier with the objective of fulfilling the requirements of the institution with the hope of a positive response being high. Collaboration of members of the Brazilian Society of Cardiovascular Surgery (BSCVS) with their suggestions will be of valuable help.

We are also in the advanced phase of implanting Continuous Medical Education (CME) in the site (www.rbccv.org.br), in tune with major international journals in our area. The system is simple: in every issue there will be an icon. On clicking, a questionnaire will be shown with questions on the content of the journal. After answering, if the replies are correct, a certificate will be issued which will count points for the revalidation of the title of specialist.

When the system is ready to be implanted, members will receive detailed instructions on how to use it. I am certain that the CME will be of great use and be frequently accessed. Similar to indexation to ISI, suggestions will be very welcome.

Aiming to assist authors and peer reviewers, we are constantly improving the journal and site. A few weeks ago, peer reviewers received by e-mail the upto-date Portuguese version of the Vancouver Norms, which are also available at the electronic address: http:/ /www.rbccv.org.br/portugues/normas_vancouver.asp. Remember that the Vancouver Norms serve as a basis for the Instructions for Authors of periodicals in the area of healthcare and consulting them helps to produce articles within the highest scientific standards.

Another new feature is a link to a page that lists the most commonly used descriptors in the BJCVS, both in Portuguese and English. To access this, it is necessary to be registered in the site. After inputting the login ID and password, a link appears in the green menu at the top of the page. Using the correct descriptors, apart from facilitating the work of editing the journal, enables simpler localization of the article thereby increasing the chance that it will be cited in the future. A list is also published in this edition.

Both the decision to send the Vancouver Norms in Portuguese and to create a list of the most commonly used descriptors were taken at a meeting of the Editorial Board of the BJCVS, associated editors and the Editorial Committee during the $35^{\text {th }}$ Congress of the BSCVS in Sao Paulo. This meeting, repeating the one that occurred in the Congress of 2007, was an excellent opportunity to exchange ideas and discuss the future of our journal.

Again, the congress provided moments of reconciliation among Brazilian colleagues and foreign guests, as well as the exchange of knowledge, so essential for cardiovascular surgery to be valued in Brazil. Congratulations to the authors of prize-winning works: $1^{\text {st }}$ place - "In vitro formation of capillary tubules from human umbilical cord blood”, Dr. Paulo Brofman et al.; $2^{\text {nd }}$ place - "Troponin $\mathrm{T}$ in the cardioprotector evaluation of trimetazidin in valve surgery patients” Dr. Antônio Sérgio Martins et al.; and $3^{\text {rd }}$ place "Endovascular treatment of thoracic aortic disease results of a multicenter study”, João Carlos Leal et al.

The personality of the year, quite rightly, went to Dr. José Teles de Mendonça, who, as president of our society, made every effort for our profession to be valorized. 
I would like to take this opportunity to welcome the new directorate commanded by our brilliant colleague Dr. Gilberto Barbosa, who, due to the changes in the statute, will take office in January 2009. His much experience in the discussion of subjects important to our specialty, together with the support of the other members, guarantees him a successful mandate. As the elections have passed, differences of opinion must be forgotten and everyone should work with mutual objectives.

The Brazilian College has reasons to commemorate. Four Brazilian cardiovascular surgeons, of international standing for their contribution to medicine, were honored during the $18^{\text {th }}$ Congress of the World Society of Cardiothoracic Surgeons in Kós, Greece on April 29 2008.

Drs. Enio Buffolo, Noedir Stolf, Randas Batista and Ricardo Lima are among the top 100 doctors in the world who had their names inscribed on a plaque placed on the marble stones that support the monument of Hippocrates in the Temple of Asclepius. According to the World Society of Cardiothoracic Surgeons, the names of these professionals "will be remembered for eternity in the place of the birth of the medical profession". These honors should make us proud and serve to encourage us to further perfect our work. Congratulations to these brilliant surgeons (Read the editorial in this edition).

I request that colleagues continue to give prestige to the BJCVS. The number of accesses has remained at a high level which fills me with happiness. In May, the mean number was over 1400 per day in our site alone. This, when summed to the site of Scielo, has placed us in a position of distinction with more than 3000 accesses daily. More than 130 thousand pages of the BJCVS are accessible. We also have received a large number of manuscripts, which occasionally causes a backlog in the evaluation process, as it is necessary to carefully review each one in order to maintain the standard of the journal within the parameters demanded by Medline.

Finally, I would like to honor Dr. José Carlos de Andrade, who passed away on June $11^{\text {th }}$ in Sao Paulo. A very respectable and loved colleague of our specialty, he bravely fought over the last years of his life against his disease, providing us with an example of dedication and perseverance. He was exemplar and will remain remembered in Brazilian cardiovascular surgery.

Once again, I would like to thank my colleagues, advertisers and Directorate of the BSCVS for the support.

My warmest regards

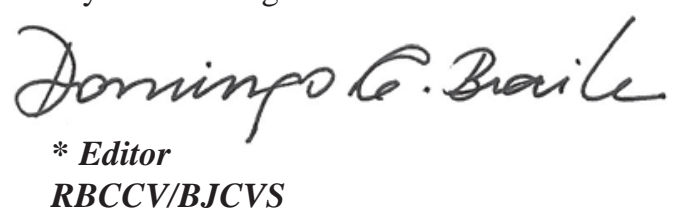

